\title{
PKM PENINGKATAN KUALITAS SUMBER DAYA MANUSIA DI RA/TK NURUL HUDA MELALUI KETERAMPILAN KOMPUTER DAN ADMINISTRASI PERKANTORAN
}

\author{
Sudi Rahayu \\ sudi_rahayu@ekuitas.ac.id \\ Iim Hilman \\ iim.hilman@ekuitas.ac.id \\ Dadang Agus Suryanto \\ a.32Surya@gmail.com
}

SEKOLAH TINGGI ILMU EKONOMI EKUITAS

\begin{abstract}
ABSTRAK
Mencerdaskan generasi penerus melalui pendidikan yang berkualitas merupakan tugas negara yang harus mendapat dukungan penuh darimasyarakat. Sistem pendidikanakan berjalan dengan baik apabila didukung dengan sumberdaya manusia yang baik pula. RA/TK Nurul Huda yang bergerak dalam dunia pendidikan anak mempunyai permasalahan dalam meningkatkan kemampuan SDM nya, khususnya di bidang pengadministrasian dan pengarsipan dokumen. Lemahnya pengadministrasian dan pengarsipan ini sering menimbulkan permasalahan, seperti misalnya data siswa, nilai, surat-surat yang hilang. Menyadari hal tersebut maka pihak sekolah meminta bantuan kepada tim pengabdian STIE Ekuitas untuk memberikan pelatihan peningkatan kemampuan SDM. Pelatihan yang diberikan berupa pelatihan MS Word, Excel, dan administrasi perkantoran. Pelatihan ini diharapkan dapat meningkatkan kemampuan guru dan staf dalam mengelola sekolah, karena melalui pelatihan MS Word, Excel guru dan staf dilatih untuk membuat arsip data nilai, soal, suratsurat, dan laporan keuangan ke dalam bentuk file dan folder agar dapat tersusun berdasarkan waktu pembuatan. Sedangkan pelatihan administrasi perkantoran dapat meningkatkan kemampuan guru dan staf dalam membuat draft surat keputusan, ekspedisi surat, dan lainlain. Hasil pengabdian akan dibuat dalam bentuk laporan dan akan dipublikasikan dalamjurnal pengabdian nasional.
\end{abstract}

Kata kunci: MS Word, Excel, Administrasi Perkantoran.

\section{PENDAHULUAN}

Peningkatan kualitas sumber daya manusia menjadi kebutuhan yang mendesak dalam menghadapi persaingan kerja yang semakin ketat, untuk itu diperlukan usaha yang maksimal dari berbagai pihak. Upaya peningkatan SDM ini tidak hanya wajib dilakukan oleh pemerintah saja, akan tetapi wajib pula dilakukan oleh lembaga-lembaga non pemerintahan dan juga seluruh masyarakat. Pemerintah berupaya meningkatkan kualitas SDM melalui pendidikan, sedangkan lembaga non 
pemerintah melalui pelatihan untuk meningkatkan keterampilan.

Peningkatan kualitas SDM wajib diberikan kepada seluruh masyarakat termasuk stafdan guru-guru non pegawainegeri, melalui peningkatan kualitas SDM diharapkan stafdan guru-guru dapat meningkatkan kemampuannya agar kelak dapat membina sekolah dengan mandiri. Masalah yang dihadapi oleh sekolah adalah keterbatasan dana yang tersedia, sehingga menyebabkan stafdan guru-guru kurang dapat mengembangkan kemampuannya, misalnya di RA/TK Nurul Huda yang mayoritas guru danstafnya kurang menguasai teknologi khususnya penguasaan tentang komputer. Padahal dengan penguasaan tentang komputer khususnya Ms Word dan Excel diharapkan mereka mampu membuat surat menyurat dan pengarsipan dengan baik Selain kebutuhan tentang penguasaan komputer, RA/TK Nurul Huda juga mempunyai keinginan untuk membekali guru dan stafnya dengan ilmu administrasi perkantoran. Permasalahan yang dialami mitra adalah rendahnya kemampuan guru dan staf dalam mengelola data-data penting, seperti data tentang siswa, nilai, laporan keuangan, surat menyurat dan lain-lain. Sehingga perlu diberikan pelatihan agar kemampuan guru dan staf dapat meningkat

\section{METODE PELAKSANAAN}

Metode kegiatan pelatihan diberikan dengan 2 cara yaitu teori dan praktek. Teori diberikan dengan tujuan untuk memberikan pengetahuan dasar tentang komputerdanadministrasiperkantoran, sedangkan praktek diberikan dengan tujuan untuk menerapkan pengetahuan yang diperoleh dalam teori kedalam kondisi nyata. Prosedur yang dilakukan dalam pengabdian inia dalah sebagai berikut:

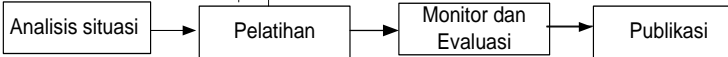

\section{HASIL DAN LUARAN}

Hasil dari kegiatan pengabdian kepada masyarakat ini dapat dilihat dari antusiasme dan respons para peserta dalam mengikuti setiap sesi pelatihan, seperti keseriusan, tingkat kehadiran, bertanya dan mengemukakan pendapat, serta berdiskusi. Sedangkan luaran dari program ini adalah meningkatnya pengetahuan dan keterampilan para peserta yang dapat diketahui melalui pelaksanaan observasi dan pemberian tugas-tugas melalui penggunaan program MS Word, MS Excel, dan dokumen serta administrasi perkantoran.

Peserta pelatihan yang terdiri atas para guru dan staf RA/TK Nuruh Huda setelah mendapat pelatihan MS Word, MS Excel dan administrasi perkantoran, dapat mempersiapkan dan membuat dokumen administrasi sendiri, mengetik dan memprint out dengan menggunakan MS Word, serta membuat laporan administrasi sederhana menggunakan MS Excel. Selain para peserta menjadi terampil menggunakan program komputer, juga peserta dilatih bagaimana menggunakan internet secara cerdas. Penggunaan internet untuk mencari sumber-sumber bahan pelajaran sekolah serta metode pembelajaran yang mutakhir. Selama pelaksanaan program pelatihan sejak awal hingga akhir para peserta dapat mengikutinya dengan serius dan antusias.

Materi pelatihan yang diberikan disesuaikan dengan kebutuhan para guru dan staf di RA/TK Nurul Huda dalam menunjang pekerjaannya. Materi pelatihan yang disampaikan dibuat sesederhana mungkin agar peserta pelatihan dapat mengikuti dan memahaminya dengan mudah, diberikan contoh-contoh yang aplikatif. Situasi dan kondisi pelatihan dibuat dalam suasana kondusif, interaktif an hidup.

Memang diakui bahwa kemampuan dan pengetahuan para guru dan staf RA/TK Nurul Huda masih berada di bawah kemampuan para guru dan staf yang bekerja di sekolah yang sudah mempunyai fasilitas teknologi dan elektronik yang lengkap, 
Dengan dilaksanakannya pelatihan ini peserta pelatihan merasa sangat terbantu dalam memahami MS Word, MS Excel dan administrasi perkantoran.

Setelah dilaksanakannya pelatihan MS Word, MS Excel dan administrasi perkantoran ini, peserta pelatihan memiliki pengetahuan dan kemampuan dalam mempersiapkan dan membuat dokumen mulai dari mengetik sampai mencetak (print-out) dokumen secara mandiri, dan melaksanakan tata administrasi serta pengarsipan surat secara baik, juga dapat menyiapkan bahan presentasi secara sederhana.

\section{Kegiatan}

pengabdian

kepadamasyarakat ini menghasilkan suatu metode, yaitu metode pengelolaan surat dan arsip berbasis elektronik, yaitu memanfaatkan program dan perangkat computer sehingga proses pengelolaan surat dan arsip lebih efektif, efisien dan sistematis.

Metode ini sangat baik diterapkan kepada guru dan staf RA/TK Nurul Huda, mengingat pada kebutuhan mengelola datadata penting seperti data tentang siswa, nilai, laporan keuangan, surat-menyurat dan lainlain.

Luaran dari pengabdian ini adalah pemberian perangkat komputer dan printer kepada RA/TK Nurul Huda, Berikut adalah beberapa dokumentasi ketika Tim Pengabdian memberikan perangkat komputer tersebut.

Dalam pelaksanaannya, keberhasilan program pengabdian ini tidak terlepas dari beberapa faktor yang mendukung dan menghambat.

\section{Faktor Penghambat}

- Lahan yang sempit dan terbatas

- Lokasi yang cukup jauh masih di daerah pedalaman

- Sarana dan prasarana yang belum memadai dalam mendukung pelaksaanan pelatihan MS Word, MS Excel dana dministrasi perkantoran.

- Para guru yang terbatas, baik dalam jumlah maupun dalam pengetahuan keterampilan komputer dan administrasi perkantoran

2. Faktor Pendukung

- Lokasi pengabdian yang berada di kota Bandung

- Dukungan finansial yang di berikan STIE Ekuitas.

- Antusiasme guru dalam menerima ilmu baru.

- Antusiasme staf dalam menjalankan program ini.

\section{KESIMPULAN}

Berdasarkan hasil pelaksanaan kegiatan pengabdian kepada masyarakat ini dan uraian pembahasan di atas, dapat disimpulkan beberapahal sebagai berikut:

1. Pelatihan ini memberikan beberapa materi yang terkait dengan upaya meningkatkan kualitas keterampilan computer dengan memberikan pengetahuan mengenai pemanfaatan Program MS Word, MS Excell dana dministrasi perkantoran dalam membuat data administrasi yang cukupsederhanasehingga proses pengelolaan surat menjadi efektif, efisien dan sistematis

2. Materi yang disajikan dapat diterima, dicerna, dan dipahami peserta dengan baik sehingga menjadikan pelatihan ini menjadi lebih kondusif. Program pelatihan dalam bentuk kegiatan melalui teori dan praktek cukup efektif, sehingga peserta dapat melihat langsung dan mempraktekkan yang disampaikan sehingga para guru RA/TK antusias mengikuti pelatihan. Pihak sekolah pun berharap di lain waktu bias belajar lagi untuk menambah pengetahuan.

3. Program pelatihan ini sangat bermanfaat dalam upaya meningkatkan kemampuan para guru dan staf dalam mengikuti pelatihan dengan penerapan kemampuan dalam pengelolaan administrasi yang baik khususanya pengelolaan database sekolah, yang pada akhirnya diharapkan akan mampu 
meningkatkan kualitas pekerjaan seluruh pihak sekolah.

4. Kegiatan berlangsung lancar, tepat waktu dan sesuai dengan yang diharapkan dan para peserta dapat berkomunikasi dengan para pembicara dan peserta lain dengan baik.

\section{DAFTAR PUSTAKA}

Daryanto, (2012).Media Pembelajaran, Bandung: Satu Nusa Lewis, Barbara A.2004. Character Building Untuk Anak-anak. Batam: Karsima Publishing

Mulyasa, (2012).Penelitian Tindakan

Sekolah. Bandung: Rosda 